\title{
Efektifitas Manajemen Penghimpunan Zakat \\ Pada Badan Amil Zakat Nasional (BAZNAS) Kota Ternate
}

\author{
Maskur Sapsuha \\ Institut Agama Islam Negeri (IAIN) Ternate \\ Basaria Nainggolan \\ Institut Agama Islam Negeri (IAIN) Ternate
}

\begin{abstract}
Abstrak
Penelitian ini bertujuan untuk menganalisis efektifitas manajemen penghimpunan dana zakat yang dilakukan oleh badan amil zakat. Badan Amil Zakat Nasional (BAZNAS) merupakan Lembaga negara yang berwenang dalam melakukan penyelenggaraan (pemungutan) zakat, infaq, dan shodaqoh. BAZNAS Kota Ternate melakukan penghimpunan zakat dari Pegawai Negeri Sipil di Pemerintah Kota Ternate. Namun, Realisasi dari pengumpulan zakat dari pegawai negeri tersebut belum efektif, ditunjukkan dari rendahnya jumlah zakat dari Pegawai Negeri Sipil yang terkumpul. Metode penelitian kualitatif lapangan dengan data primer wawancara dengan komisioner BAZNAS Ternate dan data sekunder dokumen yang relevan dengan manajemen penghimpunan dana zakat di BAZNAS kota Ternate. Hasil penelitian menyatakan, manajemen penghimpunan zakat kurang efektif karena kelemahan strategi penjangkauan calon muzaki, metode sosialisasi yang kurang tepat, dan publisitas yang kurang.
\end{abstract}

Kata Kunci: Efektifitas, Manajemen , Penghimpunan , Zakat

Abstract

The Effectiveness of Zakat Collection Management at the National Amil Zakat Agency (BAZNAS) of Ternate City-This study aims to analyze the effectiveness of the management of zakat fund collection carried out by the amil zakat agency. The National Amil Zakat Agency (BAZNAS) is a state institution authorized to administer (collect) zakat, infaq, and shodaqoh. The BAZNAS Ternate collects zakat from Civil Servants in the Ternate City Government. However, the realization of the collection of zakat from civil servants has not been effective, as indicated by the low amount of zakat collected from civil servants. Qualitative field research method with primary data is interviews with BAZNAS Ternate commissioners and secondary data documents relevant to the management of zakat fund collection in BAZNAS Ternate city. The results of the study stated that the management of zakat collection was less effective because of the weakness of the prospective muzakki outreach strategy, inappropriate socialization methods, and lack of publicity.

Keywords: Effectiveness, Management, Collection, Zakat 


\section{A. Pendahuluan}

Zakat merupakan rukun Islam ke 3 (ketiga) dari 5 (lima) rukun Islam dimana zakat itu sendiri keberadaanya memiliki nilai keimanan yang harus dimiliki oleh setiap umat muslim. ${ }^{1}$ Rasulullah shalallahu 'alaihi wassalam menempatkan zakat sebagai salah satu pilar utama dalam agama Islam. ${ }^{2}$ Seperti ritual ibadah lain dalam agama Islam, Zakat mengandung nilai-nilai yang bersifat privat-publik, verticalhorizontal, duniawi dan $\mathrm{ukhrawi}^{3}{ }^{3}$ atau dengan kata lain ibadah zakat merupakan salah satu bentuk ibadah yang mencerminkan sisi social-transendental dalam suatu ritual. 4

Jika ibadah zakat ini dapat diaktualisasikan dengan baik dan secara maksimal, maka zakat dapat menjadi salah satu sumber kekuatan yang sangat signifikan bagi tumbuh berkembangnya potensi umat Islam. ${ }^{5}$ Oleh sebab itu, saking penting dan potensialnya ibadah zakat, al-Qur'an menyebutnya sebanyak 72 kali yang dapat diartikan atau diinterpretasikan bahwa zakat memiliki urgensi yang sebanding dengan shalat. 6 Disandingkannya perintah zakat dan shalat menggambarkan bahwa kedua ibadah tersebut merupakan satu kesatuan yang tidak bisa dipisahkan urgensinya. Jika shalat adalah sarana untuk menunjukan bukti kepatuhan terhadap Tuhan, maka zakat adalah saran untuk menunjukan kepedulian kita terhadap sesame (muslim) ${ }^{7}$

Data badan pusat statistic tahun 2013 menyebutkan bahwa jumlah penduduk Indonesia yang beragama Islam mencapai 207.176.162 jumlah tersebut sebanding

${ }_{1}^{1}$ Ali Yafie, Menggagas Fikih Sosial: Dari Soal Lingkungan Hidup, Asuransi, Hingga Ukhuwah, 3rd edn (Bandung: Mizan, 1995).

2 Yamin Haddad, 'Dinamika Pengelolaan Zakat Di Indonesia' (Jakarta: Anugerah, 2017), p.

1.

${ }^{3}$ Agus Riyadi, 'Manajemen Pengelolaan Zakat Produktif Dalam Perspektif Bank Islam', Iqtishadia: Jurnal Kajian Ekonomi Dan Bisnis Islam STAIN Kudus, 7.2 (2014), 335-56 <https://doi.org/10.21043/iqtishadia.v7i2.1093>.

4 Sofwan Idris, Gerakan Zakat Dalam Pemberdayaan Ekonomi Umat, Pendekatan Transformatif, 1st edn (Jakarta: Citra Putra Bangsa, 1997).

${ }^{5}$ Idris.

${ }^{6}$ Yafie.

7 Yusuf AlQardhawi, Fiqhus Zakat (Beirut: Muassasah Risalah, 1991). 
dengan $87.18 \%$ dari seluruh penduduk Indonesia pada saat itu. ${ }^{8}$ Dilihat dari angka tersebut, maka dari sudut pandang perekonomian, jumlah yang banyak akan sebanding dengan potensi yang dimiliki. Artinya, dengan jumlah umat Islam yang besar tersebut apabila dapat menggunakan dan mengelola potensi zakat yang ada, maka pasti akan dapat menumbuhkan perekonomian umat, disebabkan ritus zakat yang merupakan ibadah yang berbentuk sosio-ekonomi memiliki kedudukan strategis terutama dalam upaya penguatan perekonomian umat. ${ }^{9}$

Sebagai bentuk ritual agama yang memiliki posisi strategis dalam mengembangkan potensi perekonomian umat, zakat memerlukan manajemen (pengelolaan) yang baik pada penyelenggaraannya. Oleh sebab itu, zakat merupakan salah satu peribadatan yang memerlukan instrument untuk melakukakannya. Pengelolaan zakat secara eksplisit disebutkan petugasnya, oleh karena zakat secara langsung maupun tidak langsung maka diperlukan manajemen agar penyelenggaraan ibadah zakat dapat berjalan secara efektif, efisien, transparan dan akuntable.

Di Indonesia instrument hukum yang mengatur tentang pengelolaan zakat ada pada Undang-Undang Nomor 23 Tahun 2011 tentang Pengelolaan Zakat, sedangkan Instrumen penyelenggara zakat ada pada Badan Amil Zakat Nasional (BAZNAS) yang juga diatur dalam Undang-Undang tersebut, dan Badan Amil Zakat dibentuk dari tingkat Nasional (Pusat), daerah Tingkat I (Provinsi) dan Daerah Tingkat II (Kabupaten/Kota), termasuk di Kota Ternate yang memiliki jumlah penduduk muslim dengan presentase $91,95 \%$ atau sebanyak 207.789 jiwa.

Besarnya jumlah penduduk muslim di Kota Ternate dapat diartikan besarnya potensi zakat yang dapat dimanfaatkan. Oleh sebab itu, BAZNAS Kota Ternate memiliki beberapa produk dan strategi pengembangan potensi perekonomian umat (selain zakat). Salah satunya adalah bekerja sama dengan pemerintah kota Ternate dalam menghimpun zakat, infaq dan shodaqoh (ZIS) kerja sama tersebut turut

8 Badan Pusat Statistik Republik Indonesia, Penduduk Menurut Wilayah Dan Agama Yang Dianut, May 2013.

9 Siti Aminah Chaniago, 'Pemberdayaan Zakat Dalam Mengentaskan Kemiskinan', Jurnal Hukum Islam IAIN Pekalongan, 13.1 (2015), 47-56. 
menyertakan beberapa Lembaga Negara yang ada di Ternate seperti Kementerian Agama dan BUMN di Kota Ternate.

Pemerintah Kota Ternate mengambil kebijakan pemungutan zakat, infaq dan shodaqoh melalui pemotongan gaji pegawai sesuai surat edaran Nomor 451/300/2011 yang disalurkan melalui Badan Amil Zakat Nasional (BAZNAS) Kota Ternate. Dari sumbangan “wajib” pegawai tersebut, terkumpul dana sebesar +/- Rp. 170.000.000,- per bulan atau kisaran 2 Miliar pertahun.

Adapun pendistribusian dana yang terkumpul tersebut adalah untuk programprogram yang dibuat BAZNAS Kota Ternate seperti, Ternate Peduli, Ternate Cerdas, Ternate Taqwa dan Pembangunan dan Rehabilitasi Ratusan Masjid dan Taman Pengajian Al-Qur'an (TPQ). Namun pertanyaan yang timbul adalah apakah tepat penyaluran zakat untuk hal-hal tersebut, mengingat bahwa ketentuan tentang penerima zakat (mustahik/asnaf) telah diatur dan tetap? Apakah sudah sesuai dengan ketentuan hukum Islam? Bagaimana BAZNAS mengelola dan mendistribusikan dana Zakat, Infaq dan Shodaqoh, mengingat peruntukan dan hukum dari ketiga hal berbeda? Dan bagaimana adat-istiadat masyarakat Ternate yang biasa menyalurkan zakatnya lewat pengurus masjid (terutama zakat fitrah pada akhir bulan ramadhan)?

Pertanyaan di atas merupakan problematika yang pengelolaan zakat yang harus dijawab, belum lagi terdapat problem-problem teknis seperti bagaimana peranan Badan Amil Zakat Nasional (BAZNAS) Kota Ternate dalam menyelenggarakan kegiatan pengelolaan dan penyaluran zakat? bagimana strategi BAZNAS Kota Ternate dalam me-manage zakat? bagaimana upaya BAZNAS dalam meningkatkan kesejahteraan melalui pengelolaan zakat di Ternate? Bagaimana efektivitas pendistribusian zakat oleh BAZNAS Kota Ternate dalam upaya mensejahterakan masyarakat Kota Ternate? bagaimana dengan tingkat kesadaran masyarakat? bagaimana tingkat kepercayaan masyarakat?

Penelitian ini menggunakan jenis penelitian kualitatif-desktriptif. Penelitian kulaitatif secara umum merupakan bentuk penelitian yang digunakan untuk penelitian tentang kehidupan masyarakat, sejarah, tingkah laku, opini, aktifitas 
social, termasuk fungsionalitas organisasi. ${ }^{10}$ Penelitian kulitatatif menjadi salah satu prosedur untuk menghasilkan data yang bersifat deskriptif baik berupa, ucapan, perbuatan, prilaku, pola pikir, opini, atau tulisan dari subjek penelitian yang diteliti.

Adapun metode pengumpulan data yang digunakan untuk mencari sumber data primer dalam penelitian ini adalah dengan observasi, wawancara, dan dokumentasi. ${ }^{11}$ Sedangkan untuk data sekunder digunakan model library research untuk mencari teori-teori pendukung dalam buku, jurnal, artikel, maupun sumber tertulis lainnya. ${ }^{12}$

Sedangkan subjek penelitian dalam penelitian ini telah ditentukan sebelumnya dengan metode purposive dengan menentukan informan yang paling sesuai (relevan) dengan tujuan dan maksud perolehan data, dengan kriteria tertentu, diantaranya, a) Para pihak yang memahami dan menguasai perihal pengelolaan dan hukum zakat, dan b) Pihak yang terlibat langsung dalam pengelolaan zakat, khususnya pada Badan Amil Zakat Nasional.

Data yang diperoleh dari informan akan ditelaah dan dianalisis menggunakan model analisis data deskriptif, artinya data yang diterima tidak akan dirubah menjadi angka-angka namun akan ditampilkan apa adanya berupa kata-kata, dengan tahapan analisis data sesuai dengan konsep Miles dan Huberman berupa a) reduksi data, b) penyajian data, c) penarikan kesimpulan. ${ }^{13}$

\section{B. Tinjauan Umum Tentang Zakat}

\section{Pengertian Zakat}

Zakat dari segi bahasa dapat diartikan sebagai keberishan atau kesucian (aththaharah), sedangkan dari segi istilah, banyak perbedaan redaksi tentang pengertian zakat namun menurut Hafhiduddin zakat ialah Sebagian harta yang diwajibkan oleh Allah swt kepada pemiliknya untuk diserahkan kepada orang

\footnotetext{
${ }^{10}$ Pupu Rahmat Saeful, 'Penelitian Kualitatif', Equilibrium, 5.9 (2019), 1-8.

${ }^{11}$ Imami Nur Rachmawati, 'Pengumpulan Data Dalam Penelitian Kualitatif: Wawancara', Indonesian Journal of Nursing, 11.1 (2007), 35-40 <https://doi.org/10.7454/jki.v11i1.184>.

12 Syaifuddin, Metode Penelitian Kualitatif Interdisipliner Ekonomi Dan Hukum Islam (Ternate: IAIN Ternate Press, 2019).

${ }^{13}$ Basuki, Interactive Qualitative Data Analysys Between Miles-Huberman And Spardley in Basuki's Dessertation (Ponorogo: Lembaga Penelitian dan Pengabdian Kepada Masyarakat (LPPM) IAIN PONOROGO, 2019).
} 
yang berhak menerimanya ${ }^{14}$ Husein Bahreij menyatakan bahwa kadar harta yang menjadi kewajiban zakat dan kriteria-kriteria orang yang berhak menerima zakat telah ditetapkan langsung oleh Allah swt melalui kitab suci Al-Qur'an. ${ }^{15}$ Sehingga kewajiban zakat menjadikannya salah satu rukun (pilar) agama Islam setelah syahadat dan shalat. ${ }^{16}$

Selain mengandung makna kesucian, zakat juga mengandung arti tumbuh dan berkembang (kesuburan), hal tersebut kemudian dapat diterjemahkan bahwa orang yang mengeluarkan zakat akan mendapatkan kesuburan hartanya dikarenakan mendapatkan keberkahan dari Allah swt, serta mendapatkan kesucian pada dirinya dan hartanya, dan hartanya tersebut akan terhindar dari segala kemudharatan. ${ }^{17}$

Ibn Mandzur dalam Lisân Arab menyatakan bahwa zakat berarti bertumbuh dan tumbuh, sehingga bisa dikatakan tanaman itu zaka, artinya tumbuh, sedangkan tiap sesuatu yang bertambah disebut zaka artinya bertambah. Bila satu tanaman tumbuh tanpa cacat, maka kata zaka disini berarti bersih. ${ }^{18}$

Sementara Syekh Yusuf Al-Qardhawi dalam Figh Zakat menyatakan bila sesorang diberi sifat zaka dalam arti baik, maka berarti orang itu lebih banyak mempunyai sifat yang baik. Seorang itu zaki, berarti seorang yang memiliki lebih banyak sifat-sifat orang baik. ${ }^{19}$

Menurut fiqih Islam, zakat berarti harta yang wajib di keluarkan dari kekayaan orang kaya untuk di sampaikan kepada mereka yang telah berhak menerimanya dengan aturan yang di tentukan dalam syara. Sedangkan Abu Hasan Al Wahidi mengatakan bahwa zakat mensucikan harta dan memperbaikinya serta menyuburkan. Menurut Asy Syaukani mengatakan bahwa zakat itu memberikan suatu bagian dalam harta yang sudah sampai

${ }^{14}$ Didin Hafhiduddin, Zakat Dalam Perekonomian Moderen (Jakarta: Gema Insani Press, 2002).

${ }^{15}$ Hussein Bahreijs, 450 Maslah Agama Islam (Surabaya: Al Ikhlas, 1980).

16 Sayyid Sabiq, Fikih Sunnah, 12th edn (Bandung: Darul Ma'arif, 1996).

17 Syaifullah Al Aziz, Fiqih Islam Lengkap 'Pedoman Hukum Ibadah Umat Islam Dengan Berbagai Permasalahannya'. (Surabaya: Terbit Terang, 2005).

18 Jamaluddin Muhammad bin Mukaram Al-Anshori Ibnu Mandzur, Lisan Al-Arab, 19th edn (Cairo: Muassasah Al-Mishriyyah al-'Ammah).

${ }^{19}$ Yusuf alQardhawi, Figh Al-Zakat (Beirut: Muassasah al-Risalah, 1997). 
nishab kepada orang fakir dan sebagainya, yang bersifat tidak bertentangan dengan syara yang tidak memperbolehkan kita memberikan kepadanya. ${ }^{20}$

Berdasarkan pendapat para ulama tersebut, dapat ditemukan pendapatpendapat dengan redaksi yang berbeda antara satu dengan yang lainya. Akan tetapi inti dari prinsipnya sama, maka dapat disimpulkan bahwa zakat zakat adalah bagian dari harta dengan prasyarat tertentu, yang Allah mewajibkan kepada pemiliknya untuk di serahkan kepada pihak yang berhak menerimanya dengan prsayarat tertentu.

\section{Hukum Zakat}

Zakat merupakan ibadah wajib yang menjadi rukun Islam. Tidak ada perbedaan pendapat para ulama terkait hal tersebut. Namun ulama berbeda pendapat tentang kapan Zakat ini diwajibkan, sebagian ulama berpendapat bahwa Zakat diwajibkan bagi umat Islam sejak tahun kedua hijriyah di Madinah, namun sebagian ulama lain berpendapat bahwa kewajiban zakat bersamaan dengan kewajiban shalat saat Nabi Muhammad saw masih di Makkah. ${ }^{21}$

Dasar hukum zakat tertera dalam Al-Qur'an dan Hadits, sebagaimana salah satu firman Allah swt dalam surat at Taubah ayat 71 yang berbunyi:

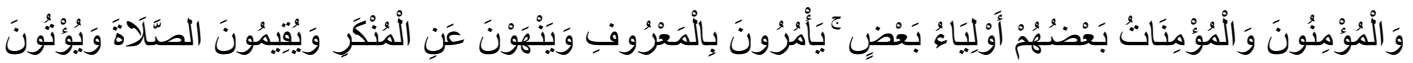

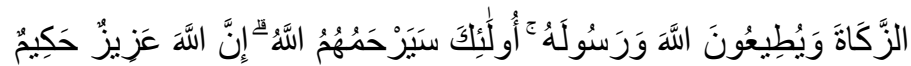

Yang artinya, dan orang-orang yang beriman, lelaki dan perempuan, sebahagian mereka (adalah) menjadi penolong bagi sebahagian yang lain. mereka menyuruh (mengerjakan) yang ma'ruf, mencegah dari yang munkar, mendirikan shalat, menunaikan zakat dan mereka taat pada Allah dan RasulNya. mereka itu akan diberi rahmat oleh Allah; Sesungguhnya Allah Maha Perkasa lagi Maha Bijaksana. (At Taubah 71).

Kemudian dalam surat At-Taubah ayat 60 Allah swt berfirman :

20 al-Qardhawi.

${ }^{21}$ Gusfahmi, Pajak Syari'ah, 1st edn (Jakarta: PT. Raja Grafindo Persada, 2007). 


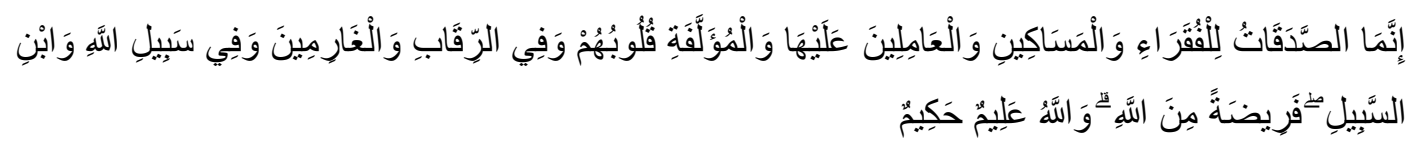

Yang artinya, Sesungguhnya zakat-zakat itu, hanyalah untuk orang-orang fakir, orang-orang miskin, pengurus-pengurus zakat, para mu'allaf yang dibujuk hatinya, untuk (memerdekakan) budak, orang-orang yang berhutang, untuk jalan Allah dan untuk mereka yuang sedang dalam perjalanan, sebagai suatu ketetapan yang diwajibkan Allah, dan Allah Maha Mengetahui lagi Maha Bijaksana. (At-Taubah 61)

Dalam surat Adz Dzariyat Allah swt berfirman:

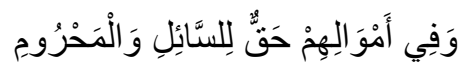

Yang artinya, Dan pada harta-harta mereka ada hak untuk orang miskin yang meminta dan orang miskin yang tidak mendapat bagian. (Adz-Dzariyat 19)

Kemudian Allah swt juga berfirman dalam surat Al-Bayyinah, yang menyatakan:

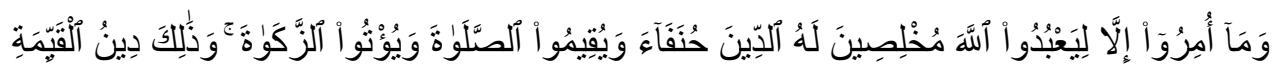

Yang artinya, Padahal mereka tidak disuruh kecuali supaya menyembah Allah dengan memurnikan ketaatan kepada-Nya dalam (menjalankan) agama yang lurus, dan supaya mereka mendirikan shalat dan menunaikan zakat; dan yang demikian itulah agama yang lurus. (Al-Bayyinah, 5)

Dan dalam Al-Qur'an surat At-Taubah Allah swt memerintahkan:

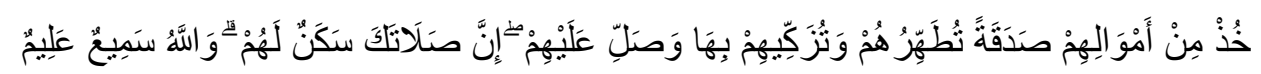

Yang artinya, Ambillah zakat dari sebagian harta mereka, dengan zakat itu kamu membersihkan dan mensucikan mereka dan mendoalah untuk mereka. Sesungguhnya doa kamu itu (menjadi) ketenteraman jiwa bagi mereka. Dan Allah Maha Mendengar lagi Maha Mengetahui. (At-Taubah 103)

Al-Qur'an Surat Ar rum ayat 39 menyatakan :

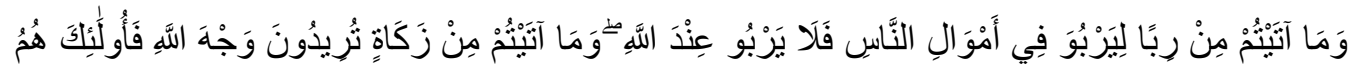

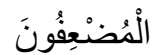

Yang artinya: Dan sesuatu riba (tambahan) yang kamu berikan agar dia bertambah pada harta manusia, maka riba itu tidak menambah pada sisi Allah. Dan apa yang kamu berikan berupa zakat yang kamu maksudkan untuk 
mencapai keridhaan Allah, maka (yang berbuat demikian) itulah orang-orang yang melipat gandakan (pahalanya).

Sementara Hadits Nabi Muhammad saw yang menerangkan tentang zakat antara lain:

Hadits Pertama:

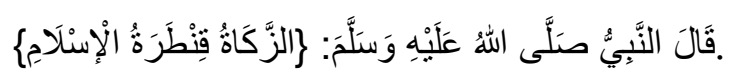

Artinya: Nabi saw. bersabda, "Zakat itu jembatannya Islam." Hadis ini diriwayatkan oleh imam Ath-Thabarani dari sahabat Abu Ad-Darda' r.a. dan diriwayatkan juga oleh imam Al-Baihaqi dari sahabat Ibnu Umar r.a.

Kemudian Rasulullah saw bersabda dalam hadits kedua:

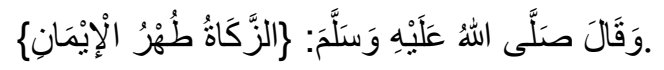

Artinya: Nabi saw. bersabda, "Zakat itu menyucikan iman." Berdasarkan penelusuran di dalam kitab Tanqihul Qaul Al-Hatsits yang merupakan syarah kitab lubabul hadits, imam An-Nawawi tidak menjelaskan periwayat hadis ini sebagaimana hadis-hadis lainnya.

Hadits ketiga Rasulullah saw bersabda:

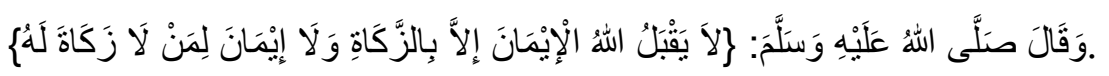

Artinya: Nabi saw. bersabda, "Allah tidak akan menerima keimanan kecuali dengan zakat. Dan tidak ada keimanan pada diri seseorang yang tidak menunaikan zakat."

Hadits keempat Rasulullah saw bersabda:

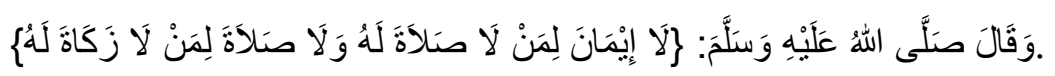

Artinya: Nabi saw. bersabda, :Tidak ada keimanan bagi orang yang tidak melaksanakan shalat, dan tidaklah sempurna shalat seseorang yang tidak membayar zakat."

Hadits kelima Rasulullah saw bersabda:

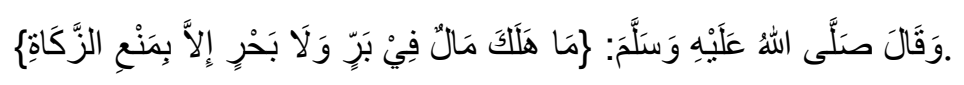

Artinya: Nabi saw. bersabda, "Tidaklah ada harta yang hancur di dalam daratan maupun lautan kecuali disebabkan dengan tidak membayar zakat."

Hadits keenam Rasulullah saw bersabda:

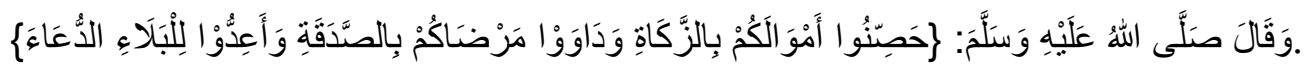


Yang artinya: Nabi saw. bersabda, "Jagalah harta-harta kalian dengan zakat, obatilah orang-orang sakit di antara kalian dengan shadaqah, dan bersiapsiaplah terhadap musibah dengan doa." Hadis ini diriwayatkan oleh imam AthThabarani, imam Abu Nuaim, dan imam Al-Khathib dari sahabat Ibnu Mas'ud r.a.

Hadits ketujuh Nabi Muhammad saw bersabda:

$$
\text { . }
$$

Yang artinya: Nabi saw. bersabda, “Tidak ada kebaikan di dalam harta yang tidak ditunaikan zakatnya." Berdasarkan penelusuran kami, perkataan tersebut adalah penggalan pidato sahabat Umar bin Khattab r.a. kepada penduduk Madinah yang diriwayatkan oleh imam Ibnu Jarir At-Thabari di dalam kitabnya Tadzhibul Atsar.

Dalam hadits yag lain, Rasulullah saw bersabda

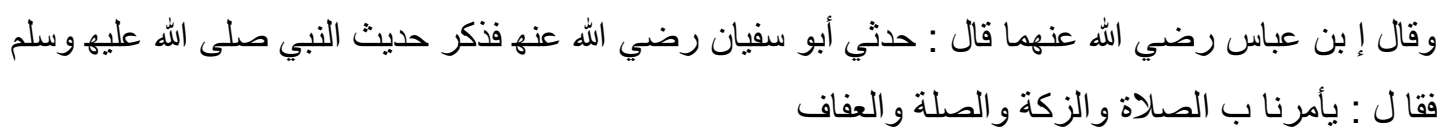

Artinya : Ibnu Abbas r.a berkata, aku diberi tau oleh Abu Sofyan r.a, lalu menyebutkan hadis nabi ia mengatakan, nabi menyuruh supaya kita mendirikan shalat, menunaikan zakat, sillaturrahmi (hubungan keluarga dan afaf, menahan diri dari perbuatan buruk. ( HR. Bukhori). ${ }^{22}$

3. Macam-Macam Zakat

a. Zakat Fitrah

Zakat fitrah merupakan zakat yang wajib di keluarkan dari awal Ramadhan hingga menjelang hari raya idul fitri oleh setiap muslimin baik tua, muda, ataupun bayi yang baru lahir. Zakat ini biasanya di bentuk sebagai makanan pokok seperti beras. Besaran dari zakat ini adalah 2,5 (dua koma lima) kg atau 3,5 (tiga koma lima) liter beras yang biasanya di konsumsi, pembayaran zakat fitrah ini bisa di lakukan dengan membayarkan harga dari makanan pokok daerah tersebut.

22 Muhammad bin Ismail Al Bukhori, Hadits Shahih Bukhori, 1st edn (Cairo: Daarul ibn Hisyam, 2003). 
Zakat ini di keluarkan sebagai tanda syukur kita kepada Allah karena telah menyelesaikan ibadah puasa. Selain itu zakat fitrah juga dapat menggembirakan hati para fakir miskin di hari raya idul fitri. Zakat fitrah juga di maksudkan untuk membersihkan dosoa yang mingkin ada ketika seseorang melakukan puasa ramadhan.

Zakat fitrah merupakan zakat jiwa (Zakat Al-Nafs), yaitu kewajiban berzakat bagi setiap individu baik untuk orang yang sudah dewasa maupun yang belum dewasa, dan di bareingi dengan ibadah puasa (Shaum).23

b. Zakat Maal

Zakat mall merupakan bagian dari harta kekayaan seseorang ( juga badan hukum ) yang wajib di keluarkan untuk golongan tertentu, setelah di miliki dalam jangka waktu tertentu, dan jumlah minimal tertentu. Dalam Undang Undang Nomor 23 Tahun 2011 tentang Pengelolaan Zakat. Pada pasal 4 ayat 2 menyebutkan bahwa harta yang di kenai zakat mall berupa emas, perak, uang, hasil pertanian dan perusahaan, hasil pertambangan, hasil peternakan, hasil pendapatan dan jasa.

Seperti diuraikan terdahulu bahwa zakat sepadan dengan kata shadaqah, juga bahkan dengan kata infaq. Ketiga istilah tersebut merupakan kata yang mengindikasikan adanya ibadah maliyah, ibadah yang berkaitan dengan harta konsep ini sudah disepakati oleh para ahli Islam. ${ }^{24}$

\section{Unsur Zakat}

Menurut Yusuf Al-Qardhawi dalam bukunya yang berjudul Hukum Zakat, mengatakan bahwa dalam zakat terdapat 4 (empat) unsur pokok dalam zakat diantaranya :25

a. Muzakki (orang yang berzakat)

Pada pasal 1 angka 5 Undang Undang Nomor 23 Tahun 2011 tentang pengelolaan zakat. Menyatakan bahwa muzakki adalah orang atau badan yang di miliki orang muslim yang berkewajiban menunaikan zakat. Zakat

${ }^{23}$ Mursyidi, Akuntansi Zakat Kontemporer, 1st edn (Bandung: PT. Remaja Rosdakarya, 2003).

24 Mursyidi.

${ }^{25}$ AlQardhawi. 
di keluarkan bagi siapa saja yang beragama Islam dan memiliki harta yang cukup haul dan nishabnya.

b. Mustahiq (Orang yang berhak menerima zakat)

Pada pasal 1 ayat 6 Undang Undang Nomor 23 Tahun 2011 tentang pengelolaan zakat. Menyatakan bahwa mustahiq adalah orang atau badan yang berhak menerima zakat. Mustahiq di sebutkan dalam ketentuan Al Qur'an surat At Taubah ayat 60 yang menyebutkan mustahiq terdapat delapan golongan di antaranya fakir, miskin, amil, mualaf, riqab, gharim, sabilillah, dan ibnu sabil.

c. Harta yang wajib di zakati

Pada pasal 4 ayat 2 Undang Nomor 23 Tahun 2011 tentang pengelolaan zakat, harta yang di kenai zakat antara lain :

1) Emas, Perak, dan Uang;

Emas dan perak dalam pengertianya merupakan logam mulia yang merupakan hasil tambang yang elok, sering dijadikan perhiasan dan mata uang dari waktu ke waktu Nishab emas adalah setara 85 gr (delapan puluh lima gram) emas murni, sedangkan perak nishab perak sebesar 672 gr (enam ratus tujuh puluh dua gram). Dan kewajiban membayar zakatnya sebesar 2,5\% (dua koma lima persen) hal ini sesuai dengan hadist riwayat Abu Daud dari Ali Bin Abi Thalib.

2) Perdagangan dan Perusahaan;

Barang yang diperdagangkan adalah suatu barang yang dapat diperjual belikan dalam rangka untuk mendapatkan keuntungan baik dilakukan individu maupun badan hukum. Nishab harta perdagangan sama dengan emas dan perak, sedangkan kadar zakatnya sebesar 2,5\% (dua koma lima persen) atau 1/40 (satu per empat puluh). Tahun perdagangan dihitung mulai dari kapan berniaga, dan pada tiap akhir tahun perniagaan dihitunglah perniagaan, apabila cukup satu nishab waka wajib dibayarkan zakatnya. 
3) Hasil Pertanian, perkebunan, dan perikanan;

Hasil pertanian adalah tumbuhan atau tanaman yang bernilai ekonomis seperti padi, dan biji-bijian. Nishab hasil pertanian pokok seperti beras, gandum, dan lain-lain adalah 5 (lima) wasq atau setara dengan $653 \mathrm{~kg}$ ( enam ratus lima puluh tiga kilo) atau $520 \mathrm{~kg}$ (lima ratus dua puluh kilo) beras dari hasil pertanian tersebut. Untuk kadar zakat yang diairi dengan air hujan, sungai, dan mata air maka kadar zakatnya sebesar 10\% (sepeluh persen), sedangkan apabila diairi dengan irigasi yang membutuhkan biaya tamabahan maka kadar zakatnya sebesar 5\% (lima persen), jika diairi dengan kedua system diatas maka kadar zakatnya sebesar 7,5\% (tujuh kona lima persen) namun apabila system pengairanya tidak di ketahui maka kadar zakatnya sebesar 10\% (sepuluh persen).

4) Hasil Tambang;

Hasil tambang adalah tempat asal tiap-tiap sesuatu, tempat penambangan emas, perak, besi, intan, minyak, batu bara dan lainya. Sedangkan pengertian lain menurut syara adalah benda yang telah diciptakan Allah di dalam bumi seperti emas, perak, tembaga, timah, dan lain-lain. Nishab barang tambang sama dengan emas 85 gr (delapan puluh lima gram) dan perak 672 gr (enam ratus tujuh puluh dua gram), sedangkan kadar zakatnya pun sama yakni 2,5\% (dua koma lima persen).

5) Hasil peternakan;

Menurut hadist Nabi yang diriwayatkan Bukhori, ternak yang wajib dikeluarkan zakatnya adalah ternak yang telah dipelihara setahun di tempat pengegembalaan dan tidak di perlakukan sebagai tenaga pengangkutan dan sebagainya. Sementara itu di Indonesia terhadap ternak yang wajib di zakati adalah kambing, domba, sapi, kerbau, unggas, ternak hasil dari perikanan, dan lain sebagainya. Berikut adalah rincian nishab dan kadar zakat dari hewan ternak hewan tersebut. 
(a) Kambing, Nishab kambing ialah 40 ekor, berdasarkan hadist Nabi yang diriwayatkan Bukhori dari Anas Bin Malik, dapat dirinci sebagai berikut :

(1) Dari jumlah 40 (empat puluh) ekor sampai 120 (seratus dua puluh) ekor, zakatnya 1 (satu) ekor kambing;

(2) Dari jumlah 121 (seratus dua puluh satu) sampai 200 (dua ratus) ekor, zakatnya 2 (dua) ekor kambing;

(3) Dari jumlah 201 (dua ratus satu) ekor sampai 300 (tiga ratus) ekor, zakatnya 3(satu tiga) kambing;

(4) Selanjutnya, setiap pertambahan 100 ekor maka zakatnya sebesar 1 (satu) ekor kambing.

(b) Sapi, Kerbau dan Kuda, Nishab kerbau,kuda, disetarakan dengan nishab sapi, yaitu 30 ekor. Menurut hadist Nabi yang diriwayatkan At Tarmidzi dan Abu daud dari Muadz bin Jabbal ketentuan nishab dan kadar zakat kerbau, kuda, dan sapi adalah sebagai berikut:

(1) Dari jumlah 30 (tiga puluh) ekor sampai 39 (tiga puluh Sembilan) ekor, maka zakatnya 1 (satu) ekor sapi betina atau jantan berumur 1 tahun (setahun) lebih, yang diberi nama tabi'i.

(2) Dari jumlah 40 (empat puluh) ekor sampai 59 (lima puluh Sembilan) ekor, maka zakatnya 1 (satu) ekor sapi betina atau jantan berumur 2 (dua) tahun lebih, yang diberi nama mussinah.

(3) Dari jumlah 60 (enam puluh) ekor sampai 69 (enam puluh Sembilan) ekor, maka zakatnya (dua) ekor sapi betina atau jantan, yang diberi nama tabi'i.

(4) Dari jumlah 70 (tujuh puluh) ekor samapai 79 (tujuh puluh Sembilan) ekor, maka zakatnya 1 (satu) ekor sapi betina, yang diberi nama mussinah. 
(5) Dari jumlah 80 (delapan puluh) ekor samapai 89 (delapan puluh Sembilan) ekor, maka zakatnya 2 (dua) ekor sapi betina, yang diberi nama mussinah.

(6) Dari jumlah 90 (sembilan puluh) ekor samapai 99 (sembilan puluh Sembilan) ekor, maka zakatnya 3 (tiga) ekor sapi betina, yang dinamai tabi'i

(7) Dari jumlah 100 (seratus) ekor samapai 119 (seratus Sembilan belas) ekor, maka zakatnya 1 (satu) ekor sapi betina tabi'i dan 2 (dua) ekor massinah.

(8) Dari jumlah 120 (seratus dua puluh) ekor samapai 129 (seratus dua puluh Sembilan) ekor, maka zakatnya 4 (empat) ekor sapi betina tabi'i dan 3 ekor sapi massinah.

(9) Dari jumlah 130 (seratus tiga puluh) ekor sapi betina, tabi'I atau 4 (empat) ekor sapi mussinah.

(10) Selanjutnya setiap penambahan 30 (tiga puluh) ekor, zakatnya satu ekor sapi tabi'I dan setiap ada pertambahan 40 (empat puluh) ekor, maka zakatnya satu ekor sapi mussinah.

(c) Peternakan Unggas dan Perikanan, Mengenai nishab zakat pada pertenakan unggas maupun perikanan yang tidak di tetapkan pada jumlah ekor maka nishab zakatnya sebesar emas yakni 85 gr (delapan puluh lima gram) dengan kadar zakat yang dikeluarkan sebesar 2,5\% (dua koma lima persen).

6) Hasil Pendapatan dan Jasa;

Zakat profesi termasuk dalam kategori zakat mall. Menurut Yusuf Al-Qardhawi zakat mall merupakan kekayaan yang diperoleh seorang muslim melalui bentuk usaha baru yang diperoleh menurut syariat agama. Selain yang disebutkan diatas, Yusuf AlQardhawi berpendapat bahwa harta hasil usaha antara lain hasil dari pekerjaan pegawai negeri atau swasta, dokter, perawat, dan lain sebagainya yang mengerjakan profesi tertentu. Nishabnya apabila penghasilan berupa uang nishabnya senilai $520 \mathrm{~kg}$ (lima 
ratus dua puluh kilo) beras, apabila diqiyaskan dengan zakat pertanian maka nishabnya sebesar 85 gr (delapan puluh lima gram), dan kadar zakatnya sebesar 2,5\% (dua koma lima persen). ${ }^{26}$

7) Rikaz

Menurut istilah rikaz adalah ketika emas, perak, dan sebagainya ialah barang yang terbenam dilapisan tanah. Sedangkan menurut istilah ahli ulama adalah barang yang disimpan dalam tanah yang berupa emas, perak, dan sebagainya sejak zaman purbakala atau sering disebut dengan harta karun termasuk di dalamanya barang yang ditemukan dan tidak ada pemiliknya. Nishab dari harta rikaz tidak terbatas, dan kadar zakat yang wajib dibayarkan sebesar 20\% (dua puluh persen). ${ }^{27}$

d. Amil (Pengelola Zakat)

Pada pasal 5 Undang Nomor 23 Tahun 2011 tentang Pengelolaan Zakat. Menyatakan bahwa yang di maksud amil zakat adalah pengelola zakat yang di organisasikan dalam suatu badan atau lembaga, sebagaimana yang di tafsirkan dalam Al Qureean At Taubah ayat 103 yang menyebutkan kata "amilinihaalaiha" sebagai salah satu yang berhak atas zakat. Kemudian di terjemahkan sebagai pengurus zakat yang bertugas mengambil dan menjemput zakat tersebut.

Sebaliknya jika zakat di serahkan secara langsung kepada mustahiq adalah sah. Akan tetapi dapat mengabaikan hal yang telah di sebutkan di atas. Selain itu hikmah dan fungsi zakat untuk mewujudkan kesejahteraan umat akan terasa sulit untuk di wujudkan.

\section{Syarat Zakat}

Menurut Elsa Kartika pada bukunya berjudul Pengantar Hukum Zakat dan wakaf pada halaman 16 (enam belas) terdapat beberapa syarat dalam ketentuan berzakat diantaranya adalah $:^{28}$

a. Syarat orang yang mengeluarkan zakat

26 alQardhawi.

27 al-Qardhawi.

28 Elsi Kartika, Pedoman Pengelolaan Zakat, 2nd edn (Semarang: UNNES Press, 2006). 
Orang yang wajib mengeluarkan zakat adalah orang atau badan yang di miliki orang muslim. Yang berkewajiban menunaikan zakat apabila memiliki kelebihan harta yang telah cukup haul dan nishabnya.

b. Syarat harta yang dizakatkan

1) Kepemilikan halal dan baik: Dapat di artikan di sini sepenuhnya berada dalam kekuasaan yang punya, baik kekuasaan pemanfaatan maupun kekuasaan menikmati hasilnya. Menurut hadist riwayat muslim, bahwa Rasulullah SAW mengatakan bahwasanya "Allah tidak menerima zakat dari harta yang tidak sah" harta yang tidak sah merupakan harta yang di peroleh dengan cara - cara yang tidak halal, atau dalam memperoleh harta tersebut menggunakan cara yang di larang agama, misalnya dengan korupsi, berjudi, menipu, mencuri, persekutuan zakat, berzina, dan lain lain.

2) Berkembang: Harta itu berkembang baik secara alami maupun berkembang secara ikhtiar atau usaha manusia. Adapula yang menyebutkan harta yang berkembang adalah harta yang produktif. Harta produktif adalah harta yang berkembang secara konkrit maupun tidak, secara konkrit dapat diartikan harta itu berkembang melalui pengembangan usaha, perdagangan, saham dan lain lain, sedangkan tidak konkrit yaitu harta tersebut berpotensi untuk berkembang.

3) Melebihi kebutuhan pokok: Harta yang di miliki seseorang itu melebihi kebutuan pokok yang di perlukan bagi diri sendiri dan keluarganya, untuk hidup wajar sebagai manusia.

4) Bersih dari hutang: Harta yang di miliki seseorang itu bersih dari hutang, baik hutang kepada Allah ( nadzar ) maupun hutang kepada sesama manusia.

5) Mencapai nishab: Harta yang di miliki oleh muzaki telah mencapai jumlah (kadar) minimal yang di keluarkan zakatnya, nishab inilah yang menjadi tolak ukur suatu harta wajib di zakati atau tidak di zakati. 
6) Mencapai haul: Harta tersebut harus mencapai waktu tertentu pengeluaran zakat. Biasanya dua belas bulan Qomariyah atau setiap kali menuai harta yang disyaratkan, cukup setahun nishabnya adalah binatang ternak, emas, perak, benatang perniagaan. Sedangkan harta yang tidak disyaratkan haulnya tiap tahun adalah tumbuh - tumbuhan yang setiap tahun menuai dan barang temuan ketika ditemukan.

c. Syarat penerima zakat

Yang berhak menerima zakat menurut Al Qur'an surat At Taubah ayat 60 antara lain :

1) Fakir miskin: Orang yang tidak mempunyai harta dan usaha atau mempunyai usaha yang kurang dari seperdua kebutuhanya, dan tidak ada orang yang berkewajiban memberi belanja. Sedangkan menurut Yusuf Al-Qardhawi dalam bukunya hukum zakat menagatakan bahwa, fakir miskin digolongkan menjadi dua kategori sebagai berikut $: 29$

a) Fakir miskin yang sanggup bekerja mencari nafkah yang penghasilanya dapat mencukupi diri sendiri dan keluarganya, seperti pedagang, petani, tukang, buruh pabrik, dan lain-lain. Akan tetapi modal dan sarana serta prasarana kurang memadai sehingga hasilnya kurang sesuai dengan kenutuhanya, maka mereka wajib diberi bantuan modal usaha sehingga memungkinkanya mencari nafkah yang hasilnya dapat mencukupi kebutuhan hidup secara layak untuk selamanya.

b) Fakir miskin yang secara mental dan fisik tidak mampu bekerja dan mencari nafkah seperti orang sakit, buta, tua, janda, anak terlantar, dan lain-lain. Mereka berhak mendapatkan bantuan zakat sampai berkecukupan, bisa juga dengan memberikan bantuan modal yang diusahakan oleh orang lain (syirkah mudharabbah) dan hasilnya memungkinkan dapat mencukupi kebutuhan hidupnya secara layak untuk selamanya.

${ }^{29}$ AlQardhawi. 
2) Amil : Amil Atau pengeumpul zakat adalah mereka yang diangkat oleh pihak yang berwenang yang akan melaksanakan kegiatan urusan zakat, baik mengumpulkan, membagikan, maupun mengelola zakat secara professional. Orang yang ditunjuk sebagai amil zakat merupakan orang yang dapat dipercaya, kejujuran, keikhlasan, sangat diperlukan amilin. Menurut hadist riwayat Abu Daud menjelaskan bahwa tidak halal bagi seorang kaya memakan harta zakat, kecualai karena lima sebab yakni:

a) Orang kaya yang menjadi amil zakat atau yang mengurus zakat;

b) Orang kaya yang membeli barang zakat dengan uangnya sendiri;

c) Orang kaya yang memiliki hutang;

d) Orang kaya yang berperang dijalan Allah;

e) Orang miskin yang diberi zakat kemudian zakat tersebut ia hadiahkan kepada orang kaya.

Allah menyediakan hadiah bagi para amilin dari harta sebagai imbalan dan tidak diambil selain harta zakat melainkan sebagai imbalan jasa dari tugas pekerjaan mereka, walupun mereka dalam kategori orang kaya. Oleh karena itu bagian untuk amilin jumlahnya tidak disamakan dengan bagian lainya seperti bagian fakir miskin, karena amilin ini diberikan bagian bukan karena kebutuhanya. Berdasarkan surat AtTaubah 60 bagian amil maksimal adalah 1/8 (satu per delapan) atau 12,5\% (dua belas koma lima persen).

3) Muallaf: Muallaf merupakan orang yang diharapkan kecenderungan dalam hatinya untuk keyakinannya dapat makin bertambah akan Islam atau dapat dikatakan sebagai orang yang baru memeluk Islam. Dengan mendapatkan bagian dari zakat akan dapat memantapkan hatinya di dalam Islam. Sementara itu, orang kafir tidak boleh dibujuk hati mereka dengan zakat. Menurut Imam Malik, Imam SyafieeI, dan Imam Ahmad, menyatakan bahwa muallaf yang hatinya dapat dibujuk dengan zakat antara lain: 
a) Orang yang baru masuk Islam dan imanya masih lemah,mereka diberikan zakat sebagai bantuan untuk meningkatkan imanya;

b) Pemimpin yang telah masuk Islam dan diharapkan akan mempengaruhi kaumnya yang masih kafir supaya mereka masuk Islam;

c) Pemimpin yang telah kuat imanya diharapkan mencegah perbuatan jahat orang kafir yang ada dibawah pimpinanya atau orang yang tidak mau memelihara zakatnya;

d) Orang yang dapat mencegah tindakan orang-orang yang tidak mau membayar zakat.

4) Riqab: adalah budak yang ingin memerdekakan diri dengan membayar uang tebusan.

5) Gharim, adalah orang yang banyak hutang, baik untuk diri sendiri maupun untuk mendamaikan orang yang berselisih maupun untuk menjamin hutang orang lain.

6) Sabilillah, adalah untuk kepentingan agama.

7) Ibnu sabil, adalah musafir yang kehabisan bekal.

d. Pengelolaan Zakat, Infaq dan Shadaqah (ZIS)

Kata pengelolaan memiliki makna yang sama dengan manajemen. Dalam Kamus Besar Bahasa Indonesia . Kata pengelolaan berasal dari kata kelola yang berarti mengendalikan, menyelenggarakan, mengurus (perusahaan, proyek dsb). Sedangkan kata pengelolaan berarti: proses, cara, perbuatan pengelola, proses melakukan kegiatan tertentu dengan menggerakkan tenaga orang lain; proses yang membantu merumuskan kebijaksanaan dan tujuan organisasi, proses yang memberikan pengawasan pada semua yang terlibat dalam pelaksanaan kebijakan dan pencapaian tujuan.

Sementara pengertian manajemen secara terminologi telah dirumuskan oleh para ahli dengan pengertian yang beragam. Adapun pergertian manajemen menurut para ahli bidang manajemen diantaranya adalah sebagai berikut : 
1) Menurut James A.F Stoner Manajemen adalah proses perencanaan, pengorganisasian dan penggunaan sumber daya organisasi lainnya agar mencapai tujuan organisasi yang telah ditetapkan.

2) Malayu S.P Hasibuan mendefinisikan manajemen adalah ilmu dan seni mengatur proses pemanfaatan sumber daya manusia dan sumber-sumber lainnya secara efektif dan efisien untuk mencapai suatu tujuan tertentu.

3) R. Terry mendefinisikan manajemen sebagai suatu proses khas yang terdiri dari tindakan-tindakan perencanaan, pengorganisasian, penggerakan dan pengendalian yang dilakukan untuk menentukan tujuan.

Dari definisi yang telah dikemukakan oleh para ahli diatas, maka dapat ditarik kesimpulan bahwa manajemen adalah proses perencanaan (planning), pengorganisasian (organizing), pelaksanaan (actuating) dan pengawasan (controlling) untuk memperoleh hasil dalam rangka pencapaian tujuan yang telah ditentukan. ${ }^{30}$

Pemahaman dari definisi tersebut di atas, terkait dengan judul penelitian ini pengelolaan yang dimaksud adalah manajemen yaitu menyangkut proses suatu aktivitas. Dalam kaitannya dengan zakat, proses tersebut meliputi sosialisasi zakat, pengumpulan zakat, pendistribusian dan pendayagunaan serta pengawasan. Sementara pengertian pengelolaan zakat secara konseptual telah dirumuskan oleh para pakar dengan pengertian yang beragam diantaranya adalah Didin Hafidhuddin berpendapat bahwa yang dimaksud dengan pengelolaan zakat adalah bahwa zakat itu diambil (dijemput) dari orang-orang yang berkewajiban untuk berzakat (muzakki) untuk kemudian diberikan kepada mereka yang berhak menerimanya (mustahiq), yang mengambil dan menjemput tersebut para petugas ('amilin).

30 Samlan Ahmad, Pendidikan Manajemen Risiko Bank, ed. by Syaifuddin (Tulungagung: Akademia Pustaka, 2021). 
Pengelolaan zakat adalah hasil harta yang dikumpulkan dari muzakki dialokasikan kepada mustahiq dengan memberikan perkakas yang memungkinkan ia bekerja dalam bidang ketrampilannya untuk mencukupi kebutuhan pokoknya. Atau bagi yang tidak dapat berniaga, juga tidak mempunyai suatu ketrampilan dalam usaha tertentu, maka kepadanya diberikan jaminan dengan jalan menanamkan modal, baik dalam harta yang tidak bergerak (tanah) maupun pada harta yang berkembang seperti peternakan (masyriah) yang penghasilannya dapat mencukupi kebutuhan pokok dalam kehidupan sehari-hari.

e. Asas-Asas Pengelolaan Zakat

Dalam UU No. 23 Tahun 2011,disebutkan bahwa asas-asas pengelolaan zakat adalah:

1) Syariat Islam. Dalam menjalankan tugas dan fungsinya, Lembaga Pengelola Zakat haruslah berpedoman sesuai dengan syariat Islam, mulai dari tata cara perekrutan pegawai hingga tata cara pendistribusian zakat.

2) Amanah. Lembaga Pengelola Zakat haruslah menjadi lembaga yang dapat dipercaya.

3) Kemanfaatan. Lembaga Pengelola Zakat harus mampu memberikan manfaat yang sebesar-besarnya bagi mustahik.

4) Keadilan. Dalam mendistribusikan zakat, Lembaga Pengelola Zakat harus mampu bertindak adil.

5) Kepastian hukum. Muzakki dan mustahik harus memiliki jaminan dan kepastian hukum dalam proses pengelolaan zakat.

6) Terintegrasi. Pengelolaan zakat harus dilakukan secara hierarkis sehingga mampu meningkatkan kinerja pengumpulan, pendistribusian, danpendayagunaan zakat.

7) Akuntabilitas. Pengelolaan zakat harus bisa dipertanggungjawabkan kepada masyarakat dan mudah diakses oleh masyarakat dan pihak lain yang berkepentingan.

f. Lembaga Amil Zakat, Infaq dan Shadaqah (ZIS) 
Organisasi pengelolaan zakat merupakan sebuah institusi yang bergerak di bidang pengelolaan zakat, infaq dan shadaqah. Lembaga pengelola zakat harus mampu memaksimalkan seluruh potensi zakat yang ada dari masyarakat, dengan melakukan pengelolaan zakat yang efektif dan efisien serta sesuai dengan syarieah. Lembaga pengelola zakat harus mampu menumbuhkan kesadaran masyarakat melalui pendekatan yang persuasif melalui sosialisasi ajaran zakat dan infaq. Lembaga pengelola zakat berhak pula mengelola zakat untuk usaha produktif dan mendistribusikan zakat pada target mustahiq yang tepat, semua itu semata-mata untuk pemerataan, keadilan dan pengentasan kemiskinan.

Lembaga pengelola zakat merupakan lembaga keuangan syariah yang paling tua. Lembaga pengelola zakat merupakan transformasi baytul mal di masa kejayaan Islam. ${ }^{31}$ Institusi yang dapat dipakai sebagai alat untuk meningkatkan kesejahteraan atau menghapuskan kemiskinan, serta dapat mendorong terjadinya keadilan distribusi harta, karena zakat diambilkan dari harta orang-orang kaya untuk kemudian dialokasikan kepada fakir miskin di daerah sekitar pemungutan zakat tersebut. Jelas ini akan terjadi aliran dana dari para hartawan kepada kaum dhuafa. Secara sadar, penunaian zakat akan membangkitkan solidaritas sosial dan mengurangi kesenjangan sosial dalam masyarakat. ${ }^{32}$

Badan Amil Zakat Nasional (BAZNAS) sebagai lembaga pengelola zakat yang didirikan oleh pemerintah untuk mengelola zakat secara nasional. Dalam pelaksanaan tugas BAZNAS menyelenggarakan fungsi:

1) Perencanaan pengumpulan, pendistribusian dan pendayagunaan zakat;

2) Pelaksanaan pengumpulan, pendistribusian dan pendayagunaan zakat;

31 Syaifuddin, Lembaga Keuangan Mikro Koperasi Syariah Tinjauan Sosial Dan Manajemen Organisasi (Idola Press Surabaya, 2015).

32 Syaifuddin, 'Metode Tafsir Aminah Wadud Untuk Pemberdayaan Perempuan Dalam Ekonomi', 1, 2019, 1-13 <https://doi.org/10.46339/al-wardah.v13i1.154>. 
3) Pengendalian pengumpulan, pendistribusian dan pendayagunaan zakat;

4) Pelaporan dan pertanggungjawaban pelaksanaan pengelolaan zakat (UU No.23 Tahun 2011).

Adapun tujuan pengelolaan zakat adalah: (1) meningkatkan efektifitas dan efisiensi pelayanan dalam pengelolaan zakat. (2) meningkatkan manfaat zakat untuk mewujudkan kesejahteraan masyarakat dan penanggulangan kemiskinan.

Secara umum, pengelolaan zakat di Indonesia belum mampu mencapai dua tujuan besar di atas. Dengan disahkannya Undang-Undang Nomor 23 Tahun 2011 tentang Pengelolaan Zakat untuk memperbaharui undangundang zakat sebelumnya, yaitu Undang-Undang Nomor 38 Tahun 1998 pada kenyataannya juga belum mampu memperbaiki sistem pengelolaan zakat yang lebih baik. Mekanisme yang diatur dalam Undang-Undang Zakat ataupun Peraturan Pemerintah Republik Indonesia Nomor 14 Tahun 2014 mengenai teknis pengelolaan zakat, pada kenyataanya belum diimplementasikan dengan baik oleh kebanyakan lembaga pengelola zakat. Ini terjadi karena lemahnya penegakan terhadap peraturan yang telah ada. Selain itu kurangnya partisipasi dan pengawasan yang baik dari pemerintah maupun masyarakat terhadap lembaga pengelola zakat dalam melaksanakan tugas dan wewenangnya sesuai dengan peraturan perundang-undangan yang berlaku. Sehingga banyak lembaga pengelola zakat dalam melakukan tugasnya terkesan kurang serius, karena belum mampu memaksimalkan potensi zakat yang ada. ${ }^{33}$

Dalam UU RI Nomor 23 Tahun 2011 tentang Pengelolaan Zakat pasal 15 ayat (1) dinyatakan bahwa "Dalam rangka pelaksanaan pengelolaan zakat pada tingkat provinsi dan kabupaten/kota dibentuk BAZNAS provinsi dan BAZNAS Kabupaten/kota". Pasal 16 ayat (1) menyatakan bahwa "Dalam melaksanakan tugas dan fungsinya, BAZNAS, BAZNAS provinsi, dan

${ }^{3}$ Syaifuddin, Lembaga Keuangan Mikro SyariahTinjauan Hukum Dan Manajemen Keuangan (Ternate: IAIN Ternate Press, 2019). 
BAZNAS kabupaten/kota dapat membentuk UPZ pada instansi pemerintah, badan usaha milik negara, badan usaha milik daerah, perusahaan swasta, dan perwakilan Republik Indonesia di luar negeri serta dapat membentuk UPZ pada tingkat kecamatan, kelurahan atau nama lainnya, dan tempat lainnya". Sedangkan dalam Pasal 17 menyatakan bahwa "Untuk membantu BAZNAS dalam pelaksanaan pengumpulan, pendistribusian, dan pendayagunaan zakat, masyarakat dapat membentuk LAZ".

Pemerintah memberikan izin pembentukan LAZ bila terpenuhi syaratsyarat yang diatur dalam pasal 18 ayat (2) yaitu terdaftar sebagai organisasi kemasyarakatan yang mengelola bidang pendidikan, dakwah dan sosial, berbentuk lembaga, berbadan hukum, mendapat rekomendasi dari BAZNAS, memiliki pengawas syariat, memiliki kemampuan teknis, administratif dankeuangan untuk melaksanakan kegiatannya, bersifat nirlaba, memilikiprogram untuk mendayagunakan zakat bagi kesejahteraan umat, dan bersediadiaudit syarieeat dan keuangan secara berkala. Dengan aturan LAZ yang ketat ini dimaksudkan agar LAZ tidak diintervensi oleh kepentingan golongan,keluarga dan kepentingan politik tertentu yang justru menjauhkan dari rasakeadilan dalam pendistribusian harta zakat.

Organisasi pengelola zakat apapun bentuk dan posisinya secara umum mempunyai dua fungsi yakni:

1) Amil berperan menghubungkan antara pihak Muzakki dengan Mustahiq. Sebagai perantara keuangan, amil dituntut menerapkan azas trust (kepercayaan). Sebagai layaknya lembaga keuangan yang lain, azas kepercayaan menjadi syarat mutlak yang harus dibangun. Setiap amil dituntut mampu menunjukan keunggulan masing-masing sampai terlihat jelas positioning organisasi, sehingga masyarakat dapat memilihnya. Tanpa adanya positioning, maka kedudukan akan sulit berkembang.

2) Perantara Keuangan, Amil berperan menghubungkan antara pihak Muzakki dengan Mustahiq. Sebagai perantara keuangan, amil dituntut menerapkan azas trust (kepercayaan). Sebagai layaknya lembaga 
keuangan yang lain, azas kepercayaan menjadi syarat mutlak yang harus dibangun. Setiap amil dituntut mampu menunjukan keunggulan masing-masing sampai terlihat jelas positioning organisasi, sehingga masyarakat dapat memilihnya. Tanpa adanya positioning, maka kedudukan akan sulit berkembang.

3) Pemberdayaan, Fungsi ini, sesungguhnya upaya mewujudkan misi pembentukan amil, yakni sebagaimana muzakki menjadi lebih berkah rezekinya dan ketentraman kehidupannya menjadi terjamin di satu sisi masyarakat Mustahiq tidak selamanya tergantung dengan pemberian bahkan dalam jangka panjang diharapkan dapat berubah menjadi Muzakki baru.

4) Sesuai dengan Peraturan Pemerintah RI Nomor 14 Tahun 2014 tentang Pelaksanaan UU Nomor 23 Tahun 2011 tentang Pengelolaan Zakat Pasal 3 ayat (1) dinyatakan bahwa "BAZNAS sebagaimana dimaksud dalam Pasal 2 merupakan lembaga yang berwenang melakukan tugas Pengelolaan Zakat secara nasional" dan ayat (2) yang menyatakan bahwa "dalam melaksanakan tugas sebagaimana dimaksud pada ayat (1), BAZNAS menyelenggarakan fungsi:

a) Perencanaan, pengumpulan, pendistribusian dan pendayagunaan zakat;

b) Pelaksanaan, pengumpulan, pendistribusian dan pendayagunaan zakat;

c) Pengendalian, pengumpulan, pendistribusian dan pendayagunaan zakat; dan

d) Pelaporan dan pertanggungjawaban pelaksanaan pengelolaan zakat.

Oleh karena itu Khasanah mengemukakan bahwa organisasi pengelola zakat bisa berjalan secara baik harus didukung oleh sumber daya manusia yang memenuhi kualifikasi tertentu.secara umum kualifikasi amil adalah: muslim, amanah, jujur dan paham fikih zakat. 
Dalam menjalankan perannya sebagai organisasi pengelola zakat ada tiga prinsip yang menjadi ukuran kinerja Lembaga Pengelola Zakat, yaitu:

1) Amanah, Sifat amanah merupakan syarat mutlak yang harus dimiliki oleh setiapamil zakat.Hal ini penting karena zakat dari para muzakki merupakan titipanyang harus dijaga tanpa menyelewengkannya. Tanpa adanya sifat amanah,sistem yang dibangun manajemen akan hancur, layaknya hancurnyaperekonomian bangsa ini yang lebih banya disebabkan rendahnya moral para pelaku ekonomi. Secara esensial dana yang dikelola oleh amil adalah danasukarela yang diperuntukkan untuk mustahik.

2) Profesional, Sifat amanah saja belum cukup, harus diimbangi dengan profesionalitas pengelolaanya. Lembaga amil zakat perlu dijadikan sebagai lembaga profesi dengan sistem penggajian. Untuk itu salaah satu caranya adalah pengelolaanya harus memperhatikan serta meningkatkan pengetahuandan keterampilan kerja, bekerja purna waktu dan digaji secara layak, sehingga segenap potensi untuk mengelola dana zakat secara baik dapat dicurahkan.Amil yang profesional selalu fokus tanpa adanya motif mencari penghasilan tambahan yang dapat mengganggu pekerjaanya selaku amil zakat. Dengan profesionalitas yang tinggi, maka pengelolaan zakat akan optimal, efektif dan efisien.

3) Transparan, Transparan merupakan suatu sistem keterbukaan sebagai kontrol yang baik. Tidak hanya melibatkan pihak internal organisasi saja tetapi juga akan melibatkan pihak eksternal organisasi seperti muzakki dan masyarakat luas. Transparan dapat meminimalisir rasa curiga dan ketidakpercayaan masyarakat.

Zakat yang dikelola oleh lembaga pengelola zakat akan memiliki beberapa keuntungan, antara lain; Pertama, menjamin kepastian dan disiplin pembayar zakat. Kedua, menjaga perasaan rendah diri para mustahik(penerima zakat) dari para muzakki (pembayar zakat).Ketiga, untuk mencapai efisiensi dan efektifitas, serta sasaran yang tepat dalam penggunaan harta zakat. Keempat, 
untuk syi'ar Islam dalam semangat penyelenggaraan pemerintahan yang Islami. Meskipun, secara hukum syari'ah adalah sah,apabila zakat diserahkan secara langsung oleh muzakki kepada mustahiq.

\section{Penghimpunan Zakat di Kota Ternate}

Kota Ternate dahulu merupakan pusat dari pemerintahan Kesultanan Ternate dengan sistem pemerintahan dan pemberlakuan hukum Islam. Artinya, sebagai pemerintahan Islam sudah tentu zakat sebagai ibadah ritual keagamaan tentu mendapatkan perhatian penting dari pemerintahan Kesultanan Ternate. ${ }^{34}$

Pada saat itu, wewenang pengelolaan zakat diberikan kepada Bobato Akherat (Pejabat Pemerintah Urusan Agama) yang dipimpin oleh seorang Jou Kalem (Menteri Agama) yang merangkap sebagai Imam Besar Masjid Sultan sekaligus Qadhi (Hakim Agung) Kesultanan Ternate. Praktis pengelolaan Zakat pada zaman ini diserahkan kepada perangkat keagamaan (Bobato Akherat) yang pelaksanaan teknisnya dilakukan oleh para Imam Masjid, para Khatib, dan Modim (Pengurus Masjid) untuk disalurkan kepada Masyarakat. Artinya, pada masa itu Masjid selain sebagai tempat melakukan ibadah ritual berupa shalat, namun juga digunakan sebagai tempat untuk menyalurkan zakat. dan Perangkat pengurus masjid juga sebagai amil zakat. yang mana kesemua perangkat keagamaan tersebut (imam, khatib, modim) teresebut diangkat oleh Sultan untuk menjalankan tugas penyelenggaraan peribadatan termasuk zakat. ${ }^{35}$

Hal tersebut berlangsung hingga bergabungnya Ternate kepangkuan Negara Kesatuan Republik Indonesia hingga saat ini penyaluran Zakat, Infaq, dan Shodaqoh juga masih berlangsung di Masjid-masjid di seputaran Kota Ternate. Namun, penyelenggaraan penerimaan zakat di Masjid-masjid pada saat ini tidak lagi memiliki legal-formal (pengangkatan oleh penguasa) seperti masa pemerintahan Kesultanan Ternate, artinya belum ada aturan hukum yang mengatur tentang pengelolaan zakat secara spesifikpada saat ini. Baru pada tahun 1999

34 Wawancara dengan Hi. Hidayatussalam (Mufti Majojo) Kesultanan Ternate 14 Juni 2019

35 Wawancara dengan Hi. Hidayatussalam (Mufti Majojo) Kesultanan Ternate 14 Juni 2019 
pengelolaan zakat memiliki kepastian hukum dengan diterbitkannya UndangUndang Nomor 38 Tahun 1999 tentang Pengelolaan Zakat. ${ }^{36}$

Pada Tahun 2005 Pengelolaan Zakat di Kota Ternate mulai terorganisir dengan dibentuknya Badan Amil Zakat Daerah (BAZDA) yang menjalankan amanat Undang-Undang Nomor 38 Tahun 1999 tentang Pengelolaan Zakat.

Seiring dengan diperbaharui Undang-Undang Pengelolaan Zakat dengan diterbitkannya Undang-Undang Nomor 23 Tahun 2011 tentang Pengelolaan Zakat, maka penamaan Badan Amil Zakat Daerah (BAZDA) telah diubah menjadi Badan Amil Zakat Nasional (BAZNAS) dan berlaku hingga saat ini. Adapun, unsur pimpinan pengurus BAZDA/BAZNAS dari tahun ke tahun adalah sebagai berikut: ${ }^{37}$

Tabel. 1

Pimpinan Baznas dari Masa Kemasa

\begin{tabular}{|l|l|l|}
\hline Tahun (Periode) & \multicolumn{1}{|c|}{ Nama } & \multicolumn{1}{|c|}{ Keterangan } \\
\hline 2005 s/d 2008 & Hi. Anis Abbas, S.IP & BAZDA \\
\hline 2008 s/d 2011 & Hi. Hamid Rachman, S.IP & BAZDA \\
\hline 2011 s/d 2016 & Hi. Sudin Robo & BAZNAS \\
\hline 2016 s/d sekarang & Hi. Anis Abbas, S.IP & BAZNAS \\
\hline
\end{tabular}

Sumber data: Badan Amil Zakat Nasional Kota Ternate

Berdasarkan keputusan Walikota Ternate Nomor 182/1.5/KT/2016 tentang Pimpinan Badan Amil Zakat Nasional (BAZNAS) Kota Ternate Periode 2016-2021 dengan pengurusan sebagai beritkut:

Tabel. 2

Struktur Pengurus BAZNAS Kota Ternate Periode 2016-2021

\begin{tabular}{|c|l|c|}
\hline No & \multicolumn{1}{|c|}{ Nama } & Jabatan \\
\hline 1. & Hi. Anis Abbas, S.IP & Ketua \\
\hline 2. & Drs. Hi. Barham Hi. Dayyan, M.M. & Wakil Ketua I Bid. Pengumpulan \\
\hline 3. & Drs. Hi. Safri Hasan & Wakil Ketua II Bid. Pendistribusian \\
\hline
\end{tabular}

36 Wawancara dengan Hi. Hidayatussalam (Mufti Majojo) Kesultanan Ternate dan Hi. Anis Abbas (Ketua BAZNAS KotaTernate) 14 Juni 2019

37 Data BAZNAS Kota Ternate 


\begin{tabular}{|c|c|c|}
\hline 4. & Hi. Natsir Tjan, S.Pd & $\begin{array}{c}\text { Wakil Ketua III Bid. Pernecanaan } \\
\text { Keuangan }\end{array}$ \\
\hline
\end{tabular}

Di bawah kepengurusan BAZNAS Kota Ternate Periode 2016-2021 Visi dari BAZNAS Kota Ternate adalah:

“Menjadikan Badan Amil Zakat Nasional (BAZNAS) Kota Ternatesebagai lembaga yang amanah, profesional, transparan dan akuntabel dalam pengelolaan zakat, infak dan sedekah (ZIS) yang turut serta dalam pengentasan kemiskinan dan pemberdayaan ekonomi umat." 38

Sedangkan misi dari BAZNAS Kota Ternate adalah: ${ }^{39}$

a. Meningkatkan partisipasi masyarakat dalam menunaikan kewajiban berzakat;

b. Mengoptimalkan peran pendayagunaan zakat melalui program kemandirian masyarakat untuk meningkatkan dampak pembangunan dan kepercayaan publik melalui pengelolaan zakat yang Amanah, Profesional, Transparan dan Akuntabel;

c. Mengkoordinasikan pengelolaan zakat untuk meningkatkan solidaritas pada Unit Pengumpul Zakat (UPZ) tentangprogram-program Badan Amil Zakat Nasional (BAZNAS) Kota Ternate.

Dan tujuan dari BAZNAS Kota Ternate Periode 2016-2021 adalah:40

a. Mengupayakan dan memelihara kesejahteraan hidup manusia lahir dan batin;

b. Menjadi sarana pengumpul zakat yang dapat memfasilitasi wajib zakat untuk melaksanakan rukun Islam yang ke-3;

c. Menjadi sarana pendistribusian zakat yang dapat memberikan manfaat kepada umat.

Untuk menjalankan visi, misi, dan tujuan tersebut BAZNAS Kota Ternate bukan hanya melaksanakan penyelenggaraan penerimaan zakat saja, namun juga

38 Dokumen BAZNAS Kota Ternate

39 Dokumen BAZNAS Kota Ternate

40 Wawancara dengan Hi. Barham Hi. Dayyan (Wakil Ketua I Bid.Pengumpulan BAZNAS Kota Ternate), 20 Juli 2019 
peneyelenggaraan penerimaan Infaq, dan Shodaqoh, dengan menggandeng Pemerintah Daerah dan Instansi-Instansi Pemerintahan lain untuk menyelenggarakan infaq dan shodaqoh yang didistribusikan melalu BAZNAS Kota Ternate.

Pemetrintah kota Ternate melalui edaran Walikota Ternate Nomor 451/300/2011 melakukan pemotongan gaji pegawai sebagai bentuk infaq yang didistribusikan lewat BAZNAS Kota Ternate dengan rincian, sebagai berikut: ${ }^{41}$

Tabel. 3

Nilai Potongan Gaji/Tunjangan PNS untuk Data Infaq Berdasarkan Nota Dinas Walikota 451.12/85/2011 dalam Edaran Walikota Nomor 451/300/2011

\begin{tabular}{|l|l|}
\hline \multicolumn{1}{|c|}{ Jumlah Gaji } & \multicolumn{1}{c|}{ Besaran Potongan Infaq } \\
\hline Rp. 1 Juta - Rp. 2 Juta & Rp. 20.000,- \\
\hline Rp. 2 Juta - Rp. 3 Juta & Rp. 40.000,- \\
\hline Rp. 3 Juta - Rp. 4 Juta & Rp. 60.000,- \\
\hline Rp. 4 Juta - Rp. 5 Juta & Rp. 80.000,- \\
\hline Rp. 5 Juta - Rp. 6 Juta & Rp. 100.000,- \\
\hline Rp. 6 Juta - Rp. 7 Juta & Rp. 120.000,- \\
\hline \multicolumn{1}{|c|}{ Rp. 7 Juta } & Rp. 140.000,- \\
\hline
\end{tabular}

Penerimaan dari sektor infaq ini per-tahun bisa mencapai kisaran 2 miliar, yang mana peruntukannya didistribusikan pada beberapa program kegiatan, seperti: Pengembangan Taman Pengajian Qur'an, insentif Guru-Guru TPQ, Insentif Imam Masjid di Kota Ternate, pembangunan dan perawatan Masjid, santunan Yatim, fakir, miskin, Sunatan (Khitanan) Masal, Beasiswa bagi masyarakat tidak mampu dan lain sebagainya. ${ }^{42}$

Meskipun begitu, beberapa masyarakat masih menganggap sinis peraturan pemerintah kota Ternate tentang kewajiban Infaq ini, mereka menganggap bahwa infaq seharusnya tidak dapat dipaksakan, hamper sama dengan shodaqoh, infaq merupakan sumbangan "sukarela" dari seseorang kepada yang lain. Pemotongan secara sepihak penghasilan pegawai untuk keperluan infaq dianggap menyalahi kaidah hukum infaq yang sesungguhnya. Penyaluran Zakat saja harus melihat nisab

41 Dokumen BAZNAS Kota Ternate

42 Wawancara dengan Drs. Hi. Safri Hasan (Wakil Ketua II Bid. Pendistribusian) 17 Juli 2019 
(takaran jumlah harta) dan haul (periode kepemilikan harta) dan dilakukan melihat kondisi muzakki (pegawai), apakah si muzakki (pegawai) itu punya hutang, apakah penghasilan si pegawai mencukupi kebutuhan sehari-harinya atau malah kurang? Dan banyak indicator yang lain, apa lagi jika yang dilakukan tersebut hanya Infaq atau shodaqoh, tentu harus memperhatikan situasi dan kondisi para pihak. ${ }^{43}$

Hal ini tentunya harus diperhatikan oleh Pemerintah dan Penyelenggara BAZNAS, jangan hanya melihat potensi penerimaan zakat yang menggiurkan, namun juga harus melihat kondisi pihak yang dibebankan, agar penerapan syariat dapat mewujudkan rasa keadilan dan kemanfaatan bagi semua pihak.

\section{Strategi Penghimpunan Zakat BAZNAS Kota Ternate}

Agar penghimpunan dana zakat tersebut tepat sasaran, maka BAZNAS Kota Ternate menyusun beberapa strrategi, diantaranya: 44

a. Membuat Perencanaan, Penghimpunan, Pengelolaan, Kontrol penyelenggaraan penerimaan Zakat di Kota Ternate;

b. Peningkatan Kualitas Sumber Daya Manusia;

c. Bekerja sama dengan Tokoh Agama dan Masyarakat untuk menumbuh kembangkan kesadaran masyarakat terhadap pentingnya penyaluran zakat yang baik dan benar;

d. Bekerja sama dengan Masjid-masjid dengan membentuk Unit Penerima Zakat (UPZ) di masing-masing Masjid di Kota Ternate;

e. Bekerja sama dengan Media Massa untuk melakukan sosialisasi dan pelaporan penerimaan dan penyaluran zakat di Kota Ternate;

f. Bekerja sama dengan stakeholder terutama pemerintah Daerah dan Lembaga Negara dan BUMN yang ada di Kota Ternate dalam melakukan penyaluran zakat dan infaq melalui BAZNAS

Dalam hal pengumpulan infaq pegawai dinyatakan belum efektif disebabkan karena belum adanya perencanaan yang tepat atas pengumpulan infaq seperti penyusunan target dan sasaran, pengumpulan infaq sebagian besar berasal dari

43 Wawancara dengan Habib Fauzi Bin Muhammad Assagaf (Tokoh Agama) 18 Juli 2019

44 Wawancara dengan Hi. Anis Abbas (Ketua BAZNAS Kota Ternate) 14 Juni 2019 
pegawai di lingkungan Pemerintahan Kota Ternate sedangkan Kementerian/Lembaga, BUMN dan BUMD belum merata pengumpulan infaqnya, tingginya kebutuhan pegawai Kota Ternate yang turut mempengaruhi jumlah infaq yang diterima.

\section{E. Penutup}

Pemerintah Kota Ternate sedang berupaya meramaikan penyaluran Zakat Infaq dan Shodaqoh melalui Lembaga Badan Amil Zakat Nasional (BAZNAS) Kota Ternate, kebijkan tersebut sebagai upaya pemerintah kota dalam meningkatkan kesadaran dalam beramal melalui Lembaga resmi. Produk layanan BAZNAS selain menghimpun zakat adalah dengan menghimpun dana infaq dan shodaqoh yang telah menjadi iuran wajib bagi pegawai negeri sipil (PNS) di Kota Ternate, meskipun sempat menimbulkan polemic, namun faktanya dana yang terkumpul per-tahun dari sumbangan infaq tersebut cukup besar. BAZNAS berupaya untuk melakukan pengumpulan zakat dari umat dan pendistribusiannya kepada orang yang berhak dengan efektif, efisien dan akuntabel. Meskipun begitu, pelaksanaan penerimaan zakat, infaq dan shodaqoh di BAZNAS cenderung fluktuatif, hal tersebut disebabkan salah satunya adalah kurangnya pemahaman masyarakat dan system manajerial yang masih harus selalu diperbaiki.

\section{DAFTAR PUSTAKA}

Ahmad, Samlan, Pendidikan Manajemen Risiko Bank, ed. by Syaifuddin (Tulungagung: Akademia Pustaka, 2021)

alQardhawi, Yusuf, Figh Al-Zakat (Beirut: Muassasah al-Risalah, 1997)

AlQardhawi, Yusuf, Fiqhus Zakat (Beirut: Muassasah Risalah, 1991)

Al Aziz, Syaifullah, Fiqih Islam Lengkap 'Pedoman Hukum Ibadah Umat Islam Dengan

Berbagai Permasalahannya'. (Surabaya: Terbit Terang, 2005)

Badan Pusat Statistik Republik Indonesia, Penduduk Menurut Wilayah Dan Agama Yang Dianut, May 2013

Bahreijs, Hussein, 450 Maslah Agama Islam (Surabaya: Al Ikhlas, 1980) Basuki, Interactive Qualitative Data Analysys Between Miles-Huberman And Spardley in 
Basuki's Dessertation (Ponorogo: Lembaga Penelitian dan Pengabdian Kepada Masyarakat (LPPM) IAIN PONOROGO, 2019)

Al Bukhori, Muhammad bin Ismail, Hadits Shahih Bukhori, 1st edn (Cairo: Daarul ibn Hisyam, 2003)

Chaniago, Siti Aminah, 'Pemberdayaan Zakat Dalam Mengentaskan Kemiskinan', Jurnal Hukum Islam IAIN Pekalongan, 13.1 (2015), 47-56

Gusfahmi, Pajak Syari'ah, 1st edn (Jakarta: PT. Raja Grafindo Persada, 2007)

Haddad, Yamin, 'Dinamika Pengelolaan Zakat Di Indonesia' (Jakarta: Anugerah, 2017), p. 1

Hafhiduddin, Didin, Zakat Dalam Perekonomian Moderen (Jakarta: Gema Insani Press, 2002)

Ibnu Mandzur, Jamaluddin Muhammad bin Mukaram Al-Anshori, Lisan Al-Arab, 19th edn (Cairo: Muassasah Al-Mishriyyah al-'Ammah)

Idris, Sofwan, Gerakan Zakat Dalam Pemberdayaan Ekonomi Umat, Pendekatan

Transformatif, 1st edn (Jakarta: Citra Putra Bangsa, 1997)

Kartika, Elsi, Pedoman Pengelolaan Zakat, 2nd edn (Semarang: UNNES Press, 2006) Mursyidi, Akuntansi Zakat Kontemporer, 1st edn (Bandung: PT. Remaja Rosdakarya, 2003)

Rachmawati, Imami Nur, 'Pengumpulan Data Dalam Penelitian Kualitatif:

Wawancara', Indonesian Journal of Nursing, 11.1 (2007), 35-40

<https://doi.org/10.7454/jki.v11i1.184>

Rahmat Saeful, Pupu, 'Penelitian Kualitatif', Equilibrium, 5.9 (2019), 1-8

Riyadi, Agus, 'Manajemen Pengelolaan Zakat Produktif Dalam Perspektif Bank

Islam', Iqtishadia: Jurnal Kajian Ekonomi Dan Bisnis Islam STAIN Kudus, 7.2 (2014),

335-56 <https://doi.org/10.21043/iqtishadia.v7i2.1093>

Sabiq, Sayyid, Fikih Sunnah, 12th edn (Bandung: Darul Ma'arif, 1996)

Syaifuddin, Lembaga Keuangan Mikro Koperasi Syariah Tinjauan Sosial Dan Manajemen

Organisasi (Idola Press Surabaya, 2015)

- - - Lembaga Keuangan Mikro SyariahTinjauan Hukum Dan Manajemen Keuangan

(Ternate: IAIN Ternate Press, 2019)

- - - Metode Penelitian Kualitatif Interdisipliner Ekonomi Dan Hukum Islam (Ternate: 
IAIN Ternate Press, 2019)

- - - 'Metode Tafsir Aminah Wadud Untuk Pemberdayaan Perempuan Dalam

Ekonomi', 1, 2019, 1-13 <https://doi.org/10.46339/al-wardah.v13i1.154> Yafie, Ali, Menggagas Fikih Sosial: Dari Soal Lingkungan Hidup, Asuransi, Hingga Ukhuwah, 3rd edn (Bandung: Mizan, 1995) 